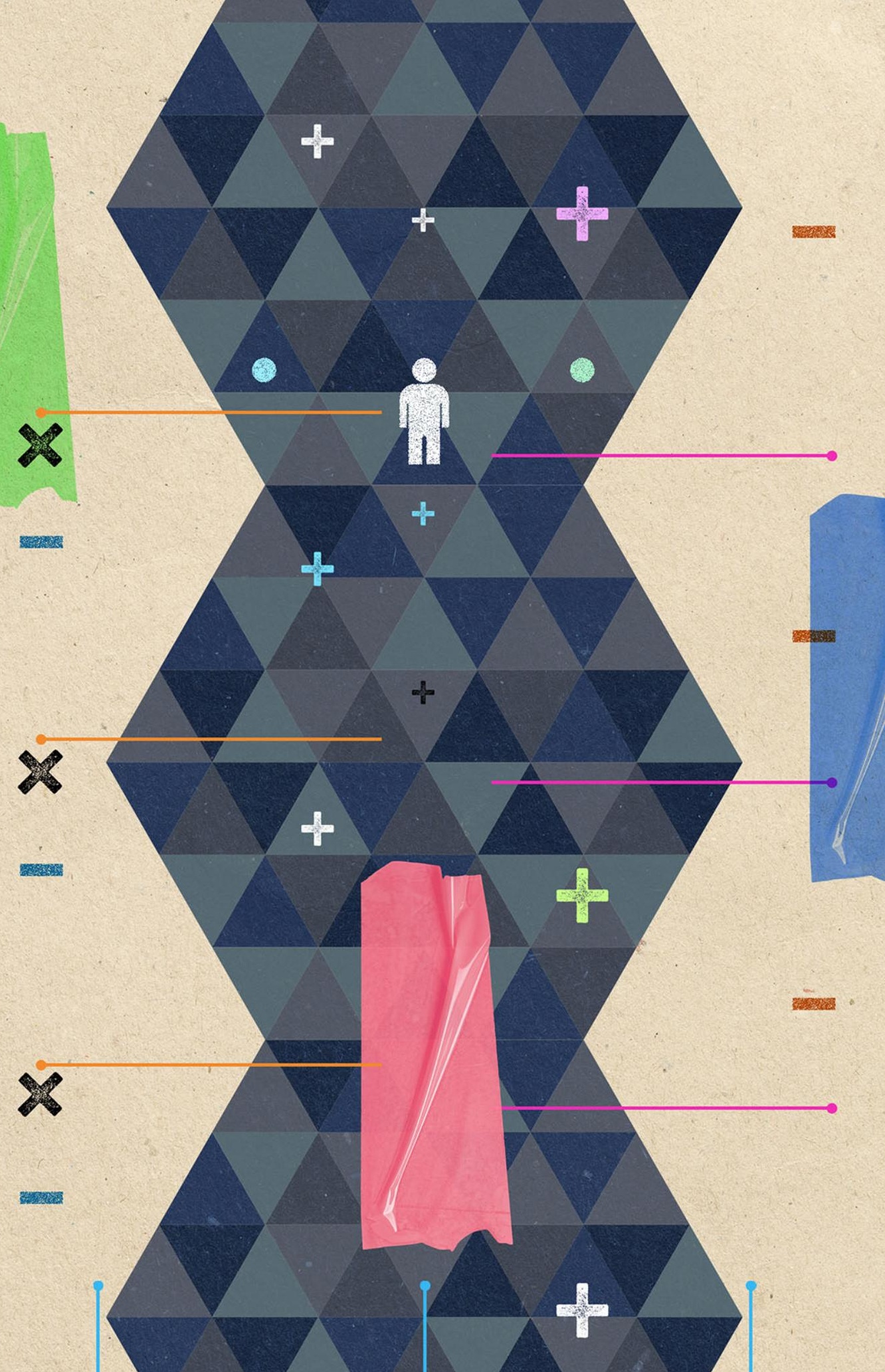




\title{
Índice de pobreza multidimensional (IPM) no Mercosul: um método sinequa non para a integração social
}

\author{
Multidimensional poverty index (IPM) in \\ Mercosur: a sine qua non method for social \\ integration
}

\author{
Leticia Diniz* \\ http://dx.doi.org/10.51861/ded.dmvu.1.005 \\ Recebido em 15 de janeiro de 2021. Aceito em 12 de março de 2021.
}

\begin{abstract}
Resumo
O trabalho tem como objetivo propor reflexões teóricas e críticas sobre quais são os métodos utilizados atualmente para mensurar a pobreza nos países do Mercado Comum do Sul (Mercosul). Para isso, realizamos uma análise bibliográfica sobre as abordagens de pobreza, principalmente a pobreza absoluta, a relativa e a multidimensional, assim como apresentamos os métodos utilizados no bloco, que em sua maioria são métodos que consideram apenas a dimensão monetária da pobreza. Por isso, a fim de transformar essa concepção unidimensional, aplicamos o IPM e o mesmo nos revelou pobrezas que atualmente são invisíveis tanto para os institutos nacionais de estatísticas como para os governos do bloco. Entendemos que é indispensável a aplicação e a criação de um índice de pobreza multidimensional (IPM) comum no Mercosul, pois o índice contribui para o fortalecimento da integração social e para a elaboração de políticas sociais em conjunto no âmbito regional.
\end{abstract}

Palavras-chave: Índice de Pobreza Multidimensional (IPM); integração social; Mercosul; métodos; políticas sociais.

\begin{abstract}
This work aims at proposing theoretical and critical reflections on what are the current methods at work for measuring poverty in the Southern Common Market (Mercosur) countries. For that, we both ran a bibliographic analysis about approaches on poverty, especially absolute, relative and multidimensional poverty, and presented the methods used within the trade bloc, which are mostly methods that address only the monetary dimension of poverty. Thus, in order to transform such unidimensional conceptualization, we applied the Multidimensional Poverty Index (IPM), which unveiled poverties that are currently invisible either for the national institutes of statistics or the governments within the bloc. We understand that it is indispensable that an IPM be created and applied within Mercorsur, because the index contributes for strengthening social integration and elaborating social policies at the regional level.
\end{abstract}

Keywords: Multidimensional Poverty Index (IPM); social integration; Mercosur; methods; social politics.

\footnotetext{
* Leticia Diniz. Graduada em Relações Internacionais pela Universidade Federal Fluminense (UFF). Mestre em Integração Contemporânea da América Latina pela Universidade Federal da Integração Latino-Americana (UNILA). https://orcid.org/0000-0002-0338-6960.E-mail: leticia_dn@live.com
} 


\section{INTRODUÇÃO}

$\mathrm{O}$ artigo origina-se da pesquisa de mestrado "Entre os conceitos importados e a realidade pulsante: o Plano Estratégico de Ação Social (PEAS) e a pobreza multidimensional no Mercosul” do Programa de pós graduação em Integração Contemporânea da América Latina na Universidade Federal de Integração Latino-Americana (UNILA).

$\mathrm{O}$ trabalho apresenta alguns dos resultados relacionados às discussóes teóricas sobre os enfoques e os métodos utilizados para mensurar a pobreza nos países membros oficiais do Mercado Comum do Sul (Mercosul). Além disso, realiza-se a elaboração de um breve diagnóstico social a partir do índice de pobreza multidimensional (IPM).

Pensar a pobreza na América Latina, dentro da área de integração regional e de economia política internacional, representa não apenas um desafio, mas um tema inovador. A dimensão social, especificamente a pobreza, parece ter sido um tema relegado à outras disciplinas, negando uma realidade existente e necessária para a evolução de qualquer integração regional.

Esta pesquisa é fortemente motivada pelo contexto atual (2021) vivenciado no Mercosul, pois o bloco passa por diferentes crises. Uma crise política, em que os governos de direita e ultra direita vigentes não acreditam em uma integração mais ampla, muito menos em qualquer forma de integração social.

Isto representa um retrocesso para a área social do Mercosul e consequentemente para a integração entre os países membros do bloco. Além disso, o Mercosul, assim como o mundo todo, enfrenta uma crise sanitária com a chegada do novo Covid-19; esta pandemia ressaltou ainda mais as falhas domésticas e dentro dos blocos regionais, em que o setor da saúde foi nitidamente sobrecarregado e insuficiente, mostrando como a população pobre sofre maiores consequências devido à ausência do Estado em suas vidas.

Ressaltamos que o Mercado Comum do Sul se constituiu em um momento de competitividade internacional e de regionalismo aberto em 1991, no entanto, tivemos o predomínio de governos progressistas, a partir de 2003, na maioria dos países da região, que possibilitaram e fomentaram o início da construção de uma dimensão social dentro do bloco, sendo que anteriormente havia somente uma dimensão econômica e comercial no âmbito regional. Isto possibilitou a criação de instituições e marcos normativos relacionados à questão social no bloco.

Dessa forma, o trabalho enquadra-se nos estudos sobre a dimensão social do Mercosul e tem como objetivo propor reflexóes teóricas e críticas sobre quais são os métodos utilizados atualmente para mensurar a pobreza nos países do bloco. 
Desse modo, os resultados da investigação estão organizados em três seções: em primeiro lugar realizamos uma análise bibliográfica sobre quais foram as abordagens e enfoques sobre a pobreza dentro do debate internacional, expomos principalmente os enfoques de pobreza absoluta, relativa e multidimensional.

Em um segundo momento, apresentamos os métodos de pobreza que são utilizados atualmente pelos países oficiais do Mercosul (Argentina ${ }^{1}$, Brasil, Paraguai, Uruguai e Venezuela ${ }^{2}$ ). Demonstramos como em sua maioria são métodos que consideram apenas a dimensão monetária da pobreza, nesta seção problematizamos e discutimos esta abordagem unidimensional, assim como realizamos uma análise crítica sobre as políticas sociais focalizadas para redução de pobreza. Por fim, com o objetivo de transformar essa concepção de unidimensional e para fortalecer a integração social e a elaboração de políticas sociais em conjunto no âmbito regional, aplicamos o índice de pobreza multidimensional, o qual revelou pobrezas em comum que atualmente são invisíveis tanto para os institutos nacionais de estatísticas como para os governos do Mercosul. Por fim, devido às limitaçóes para a aplicação do IPM na região, recomendamos a criação de um índice próprio de medição de pobreza multidimensional no Mercosul.

\section{ENFOQUES SOBRE A POBREZA: BREVE RETROSPECTIVA HISTÓRICA}

Devemos destacar que é imperioso discutir a pobreza enquanto categoria teórica, pois consideramos que esta categoria determina as práticas sociais, as ações que serão tomadas, isto é, tem efeito direto na elaboração e implementação de programas e políticas sociais.

Devemos ressaltar que existem amplos debates históricos sobre o que é pobreza. Desde o século XIX, diversas concepçóes sobre a pobreza foram elaboradas e utilizadas por Estados, organismos internacionais e intelectuais do mundo todo, como exemplo, temos: a concepção da pobreza absoluta, da pobreza relativa e da pobreza multidimensional. Os estudos de pobreza referem-se historicamente à privaçóes dos indivíduos, sejam elas de ordem material, cultural e social relacionadas aos recursos disponíveis de um indivíduo ou de sua família. Ressaltamos que as formas e concepçóes criadas para identificar os pobres em uma sociedade são um campo amplo e antigo (CRESPO, 2002).

Conscientes desse espaço temporal extenso e de uma bagagem histórica ampla, em primeiro lugar apresentaremos a pobreza absoluta. A pobreza absoluta foi uma das primeiras abordagens sobre o que é pobreza desde 
os estudos do século XX. O expoente desta abordagem é o autor Joseph Rowtree que cunhou este termo a partir de seus estudos sobre os pobres na Inglaterra. Nesta abordagem, a pobreza é vista como o padrão mínimo para a sobrevivência dos seres humanos, isto é, para suprir suas necessidades básicas (KAGEYAMA, 2006).

Questionando esta abordagem de pobreza absoluta, Peter Towsend apresentou a concepção de pobreza relativa. Para o autor, o conceito de pobreza deveria ser relativo, pois refere-se à um conjunto de condiçốes, a partir da comparação de um padrão de vida. Isto é, são considerados pobres aqueles que estão em uma camada inferior da distribuição de renda quando comparados aos outros mais bem posicionados (KAGEYAMA, 2006).

Assim, esta visão e a defesa da pobreza relativa provocou um amplo debate durante os anos 1980, liderado por Amartya Sen. O autor explica como a pobreza tem uma "irredutível essência absoluta" no sentido de que a fome e a inanição são elementos óbvios da pobreza e isso é independente da posição relativa na escala social. Por isso, para Sen a qualidade de vida dos indivíduos não se mede pela posse de diversos bens, mas pelas capacidades dos indivíduos em utilizá-los para obter felicidade ou satisfação. Este enfoque é conhecido como o de "privação de capacidades" (KAGEYAMA, 2006).

A partir das diferentes abordagens acima apresentadas sobre o conceito de pobreza (Absoluta e Relativa), três concepçóes foram decorrentes destas visões durante o século XX: a concepção de pobreza por ingressos ou sobrevivência, a pobreza a partir da satisfação das necessidades básicas e a privação relativa.

A pobreza por ingressos refere-se à renda. Toda entrada de ingresso monetário é medida a partir da possibilidade de suprir o valor da Cesta Básica de Alimentos (CBA) e assim ter o mínimo de acesso à saúde e à educação.

Este enfoque nasce no século XIX e se torna vigente até a década de 1950, também denominado como o enfoque de sobrevivência, teve origem nos estudos de nutricionistas inglesas que indicavam que a renda dos pobres não era suficiente para manter o rendimento físico dos indivíduos, restrito apenas a uma análise nutricional sobre a pobreza.

Estes estudos influenciaram na elaboração de um modelo de proteção social para o Estado de bem- estar, principalmente na Inglaterra, mas também em toda a Europa. O enfoque foi até mesmo utilizado posteriormente por organizações mundiais como o Banco Internacional para a Reconstrução e o Desenvolvimento (BIRD) (CRESPO, 2002).

A maior crítica realizada a este enfoque é de que este permitiria apenas manter os indivíduos no nível de sobrevivência, não acabando com a pobreza 
e sendo funcional apenas para limitar as demandas por reformas sociais, assim como preservaria o individualismo compatível ao ideário liberal.

Assim em 1970 a pobreza passa a ter uma conotação de necessidades básicas (NB), em que se incorporaram outros âmbitos como serviços de água potável, saúde, saneamento básico, cultura e educação. Este enfoque ampliou de forma tímida a concepção de sobrevivência física, no sentido de que se criou um patamar de consumo básico de uma família, enfoque que passou a ser adotado por organizaçóes internacionais como por exemplo a ONU.

Desta forma, em 1980, a pobreza passou a ser entendida como privação relativa. Em que sair da linha de pobreza não significava apenas obter um regime alimentar adequado, mas uma questão mais próxima do social, em que deveria existir um certo nível de conforto, desenvolvimento de papéis e de comportamentos socialmente adequados. Isto é, definindo as capacidades mais ou menos plenas para desenvolver-se, ou seja, os que alcançam ou não um padrão de vida básica.

Concomitantemente à esta concepção e em contraposição da mesma criou-se durante o "Consenso de Washington" a tese de que o bom funcionamento dos mercados e das economias geraria o efeito "gotejamento", ou seja, a riqueza gerada acabaria beneficiando também os pobres. No entanto, os efeitos desastrosos dos ajustes econômicos dos anos 90 evidenciaram a falha deste pensamento (CRESPO, 2002).

Deste modo, após grandes debates na esfera internacional chegou-se à concepção da pobreza como um fenômeno multidimensional, perspectiva que aborda "o problema em sua complexidade e interligação entre as causas e as consequências que geram e reproduzem esse fenômeno social” (SILVA, 2020, p.143).

O conceito de pobreza multidimensional tem influência dos estudos realizados por Amartya Sen, pois segundo o autor seria necessário captar todas as privações da pobreza, não somente a dimensão econômica. Por isso, além da carência econômica, os estudos multidimensionais abordam dimensóes como saúde, educação, habitação, participação política, igualdade entre sexos entre outras (CODES, 2008 apud SILVA, 2020).

Estas abordagens e conceitos deram início aos métodos e as linhas de pobreza.Assim, existem linhas de pobreza objetivas e subjetivas, assim como foram criadas linhas monetárias e linhas não monetárias, isto é, baseadas em outros critérios que não remetem à renda. 


\section{MERCOSUL E OS MÉTODOS PARA MENSURAR A POBREZA}

Após expor quais medições de pobreza são predominantes mundialmente, questionamos quais são os métodos utilizados para avaliar os níveis de pobreza nos países oficiais do Mercosul. Em primeiro lugar, explicaremos quais linhas de pobreza são utilizadas pelos membros oficiais e iremos expor se utilizam apenas um método de pobreza ou se existe uma combinação entre eles.

Isto para demonstrar principalmente que existe uma medição de pobreza em comum no bloco: a medição da pobreza absoluta e a partir dos ingressos (renda), que será posteriormente alvo de nossas discussóes e problematizações nesta seção.

Ressaltamos que existem esforços atualmente para a sistematização e harmonização dos indicadores e dados sociais do bloco: o Sistema de Informação do Mercosul sobre Políticas e Indicadores Sociais (SIMPIS) (RMADS, 2014). No entanto, apesar desses esforços, no Mercosul ainda não existe uma harmonização dos métodos de medição de pobreza; cada país utiliza um método diferente, apesar de compartilhar uma mesma perspectiva monetária.

Por isso, devemos salientar que tomamos por base o estudo realizado através do Projeto de Cooperação Estatística do Mercosul do Grupo de trabalho no 3 para a Reunião Especializada em Estatísticas do bloco (REES) denominado "Medición de la Pobreza enlos Países del Mercosur Una Propuesta de Armonización”, em que buscou-se a harmonização de métodos de pobreza no Mercosul (apenas da Argentina, Brasil, Paraguai e Uruguai).

Além deste estudo, os conceitos apresentados encontram-se em boletins técnicos dos institutos nacionais responsáveis pela elaboração de métodos de pobreza de cada país, quais sejam Instituto Nacional de Estatística e Censos (INDEC) da Argentina, Instituto Brasileiro de Geografia e Estatística (IBGE), Dirección General de Estadísticas, Encuestas y Censos (DGEEC) do Paraguai, Instituto Nacional de Estadística (INE) do Uruguai e do Instituto Nacional de Estadística (INE) da Venezuela.

Desta forma, na Argentina aplicam-se diferentes métodos para calcular a pobreza absoluta: o método de necessidades básicas insatisfeitas (NBI), a Linha de pobreza absoluta e o Índice de Privação Material de Lares (IPMH). As NBI calculam-se a partir de cinco indicadores: superlotação dentro da casa, tipo de moradia, infraestrutura sanitária, lares que tem alguma criança em idade escolar (6 a 12 anos) que não vai à escola e por último a quantidade de pessoas com ocupação e cujo chefe/a da casa tem baixa educação, até o segundo ano do fundamental (MERCOSUL, 2010). 
Mede-se também a Linha de pobreza absoluta (LP) na qual é considerada em primeiro lugar a Linha de indigência (LI), que procura estabelecer se os lares contam com ingressos suficientes para cobrir a Cesta Básica de Alimentos (CBA), capaz de satisfazer o mínimo de necessidades energéticas proteicas. Para além do consumo alimentício básico, medem-se também outros consumos básicos não alimentícios (vestimenta, transporte, educação, saúde, entre outros) e assim se constrói a Cesta Básica Total (CBT).

Assim, para calcular a Linha de Pobreza absoluta, considera-se o suprimento da CBA e dos consumos não alimentícios da CBT. É importante ressaltar que esta Cesta Básica Total reflete os hábitos de consumo da população de referência, e por isso são variantes em cada país (INDEC, 2016).

Além disso, na Argentina mede-se a pobreza a partir do Índice de Privação Material de Lares (IPMH). Trata-se de um método combinado que calcula os lares em relação à heterogeneidade da privação material, são consideradas duas dimensóes: recursos e patrimônios. No Paraguai, utilizam-se diversas mediçóes para pobreza absoluta: a metodologia de Necessidades Básicas Insatisfeitas, a Linha de Pobreza Absoluta, pobreza extrema e o mapa da pobreza.

Define-se a população pobre como aqueles lares que não cumprem com os níveis de bem estar; para isso medem-se quatro indicadores: qualidade da moradia, infraestrutura sanitária, acesso à educação e capacidade de sobrevivência da população (MERCOSUL, 2010). Considera-se a população pobre como o conjunto de pessoas que residem em lares em que o nível de ingressos é inferior a Cesta Básica de Consumo, que é composta por bens alimentícios e não alimentícios. Assim, o custo de uma Cesta Básica de Consumo é denominado de: Linha de pobreza Total (LPT). Então, a linha de pobreza total é construída a partir do custo da CBA e o conteúdo calórico e proteico minimamente satisfatório e logo adiciona-se o custo de uma cesta básica não alimentar (DGEEC, 2018).

Desta forma, considera-se que o custo mensal por pessoa da Cesta Básica de Alimentos é a Linha de Pobreza Extrema (LPE), definida como o conjunto de pessoas que vivem em lares em que seus ingressos per capita são inferiores ao custo da CBA (DGEEC,2018).

Por fim, outro método combinado é o mapa de pobreza do Paraguai, que junta informações das pesquisas domiciliares permanentes, do Censo de população e moradia do Paraguai, onde se constroem indicadores de pobreza e desigualdade para subgrupos da população definidos geograficamente (MERCOSUL, 2010). 
No Uruguai, há dois tipos de métodos para calcular a pobreza absoluta: o primeiro é o de Necessidades Básicas Insatisfeitas e o segundo é a partir da LP e da LI. As Necessidades Básicas Insatisfeitas são compostas por seis dimensões de carências críticas: tipo de moradia, superlotação, disponibilidade de água potável e sistema de infraestrutura sanitária.

No entanto, este NBI passou a chamar-se de Índice de Condiçóes de Moradia (Mercosul, 2010). Devemos ressaltar que, além desses indicadores das NBI, durante as pesquisas domiciliares existem os indicadores específicos de assistência escolar e capacidade de sobrevivência, mas se encontram em outro âmbito, fora do Índice de Condições de Moradia.

A segunda medição é da linha de pobreza calculada através da comparação do ingresso per capita dos lares considerando as linhas de indigência e de pobreza, respectivamente. Assim como em outros países do Mercosul, são classificados indigentes os que estão inferiores à linha de indigência (não supre a cesta básica de alimentos) e pobres são aqueles que estão abaixo da Linha de pobreza, composta pela cesta básica não alimentar e alimentar (INE URUGUAI, 2020).

$\mathrm{Na}$ Venezuela, existem três métodos de análise da pobreza, a Linha de pobreza mede-se conforme os ingressos familiares comparados com a Cesta Básica Alimentar e não Alimentar. Mede-se a pobreza através das necessidades básicas insatisfeitas (NBI) e possui cinco indicadores: a alta dependência econômica, o número de crianças de 7 a 12 anos que não vão à escola, o acesso a serviços básicos (água e infraestrutura sanitária), superlotação e tipo de moradia.

O produto obtido da aplicação das variáveis das NBI é utilizado para a realização do mapa da pobreza. Por fim, o terceiro método é denominado como Integrado, pois junta dados dos primeiros métodos para calcular a "pobreza crônica”, em que são considerados pobres os lares que são simultaneamente pobres por linha de ingresso e por necessidades básicas insatisfeitas (INE VENEZUELA, 2018).

A escolha de colocar o Brasil por último deve-se à complexidade dos métodos utilizados para abordar a pobreza. No Brasil, realiza-se o "mapa da pobreza”, mas devemos salientar que o IBGE utiliza diferentes métodos para avaliá-la.

Destacamos que não existe um consenso de qual linha de pobreza é oficial no Brasil; por isso, diferentes trabalhos usam suas próprias linhas de pobreza. No entanto, os autores Falcão e Costa (2014) realizaram uma discussão sobre a linha de pobreza no Programa Brasil Sem Miséria e salientam que se escolheu uma abordagem unidimensional em que a construção da linha de pobreza absoluta considera a linha de indigência a partir da cesta básica de 
alimentos (como nos outros países) a partir desta linha monetária, estabeleceu-se uma linha de $\mathrm{R} \$ 70$ mensais para a extrema pobreza e $\mathrm{R} \$ 140$ para pobreza (FALCÃO \& COSTA, 2014, apud SILVA, 2020).

Além disso, durante a elaboração da Síntese de Indicadores Sociais (SIS) do IBGE, considera-se a linha de pobreza proposta pelo Banco Mundial, em que as pessoas que vivem com um rendimento de até U\$ 5,5 por dia ou R\$ 406 por mês são consideradas pobres. Esta linha de pobreza do Banco Mundial é elaborada a partir da Paridade do Poder de Compra (PPC) (IBGE, 2018).

No Brasil, elabora-se o mapa de pobreza, um método combinado que consiste na construção do perfil detalhado da pobreza a partir da junção de diversas fontes de dados. O objetivo principal é poder coletar informaçóes mais detalhadas de áreas pequenas, e a elaboração deste mapa considera medidas de pobreza absoluta e de pobreza subjetiva.

A linha de pobreza subjetiva utilizada no Brasil parte do pressuposto de que o bem estar do indivíduo está influenciado pela posição que ocupa na sociedade em relação aos demais indivíduos de um determinado grupo. Por isso, a pergunta principal deste método é: qual seria o valor mínimo mensal para cobrir os gastos da sua família? Por último, temos o uso da linha de pobreza relativa, que é construída de acordo com a distribuição dos ingressos ou consumo per capita de cada lar, onde realiza-se a mediana dos ingressos da sociedade de forma comparativa (MERCOSUL, 2010).

Tabela 1. Indicadores para medição de pobreza no Mercosul

\begin{tabular}{|c|c|c|c|c|c|}
\hline TÓPICOS & ARGENTINA & BRASIL & PARAGUAI & URUGUAI & VENEZUELA \\
\hline PERIODICIDADE & Semestral & Variável & Anual & Anual & Decenal \\
\hline $\begin{array}{l}\text { NOME DO } \\
\text { INDICADOR }\end{array}$ & $\begin{array}{l}\text { Linha de } \\
\text { pobreza } \\
\text { Linha de } \\
\text { Indigência }\end{array}$ & $\begin{array}{l}\text { Linha de } \\
\text { pobreza } \\
\text { Linha de } \\
\text { Indigência }\end{array}$ & $\begin{array}{l}\text { Linha de } \\
\text { pobreza total } \\
\text { Linha de } \\
\text { pobreza } \\
\text { extrema }\end{array}$ & $\begin{array}{l}\text { Linha de } \\
\text { pobreza } \\
\text { Linha de } \\
\text { pobreza } \\
\text { Extrema }\end{array}$ & $\begin{array}{l}\text { Linha de } \\
\text { pobreza } \\
\text { Linha de } \\
\text { pobreza } \\
\text { Extrema }\end{array}$ \\
\hline $\begin{array}{l}\text { COMBINAÇÃO } \\
\text { COM OUTROS } \\
\text { INDICADORES }\end{array}$ & $\begin{array}{l}\text { Necessidades } \\
\text { básicas } \\
\text { insatisfeitas e } \\
\text { Índice de } \\
\text { Privação } \\
\text { Material de } \\
\text { Lares (IPMH) }\end{array}$ & $\begin{array}{l}\text { Mapa da } \\
\text { pobreza } \\
\text { Linha } \\
\text { subjetiva } \\
\text { Linha } \\
\text { Relativa }\end{array}$ & $\begin{array}{l}\text { Necessidades } \\
\text { Básicas } \\
\text { Insatisfeitas e } \\
\text { Mapa da } \\
\text { pobreza }\end{array}$ & $\begin{array}{l}\text { Índice de } \\
\text { Condições de } \\
\text { Moradia }\end{array}$ & $\begin{array}{l}\text { Necessidades } \\
\text { Básicas } \\
\text { Insatisfeitas } \\
\text { Mapa da } \\
\text { pobreza } \\
\text { e Método } \\
\text { Integrado }\end{array}$ \\
\hline
\end{tabular}

Fonte: Elaboração própria. Com base no estudoProyecto de Cooperación CE-MERCOSUR enMateria Estadística Il. Medición de la pobreza en los países del Mercosur : una propuesta de armonización. Grupo de Trabalho “Estatísticas para Medición de Pobreza - GT3, 2010. Disponível em:<https://biblioteca. ibge.gov.br/visualizacao/livros/liv98454.pdf> Acesso em 07 maio 2020. 
A partir desta tabela, podemos visualizar de forma clara que há certa diversidade para abordar a linha de pobreza no Mercosul; quanto aos indicadores, no entanto, o que há em comum é o enfoque da pobreza absoluta, ou seja, a pobreza medida pelos ingressos. A maioria dos países do bloco adota o ingresso como medida do bem estar, mas a operacionalização deste conceito de pobreza tem sido alvo de discussão. A forma mais simples e comumente usada é o nível de renda, isto é, a linha de pobreza absoluta (KAGEYAMA, 2006).

No entanto, questionamos: apenas a partir do ingresso podemos afirmar que um lar é pobre? A partir dos dados econômicos conseguimos ver de fato a pobreza? Conseguimos localizar os grupos que não tem acesso à saúde, à educação e à qualidade de vida? É possível ver o desenlace destes laços que deixam a população sem trabalho, sem educação, empregadas informalmente ou vulneravelmente?

Por isso, questionamos: a partir destes indicadores econômicos conseguimos ver o fim de laços sociais? Podemos compreender como se inicia o processo de desafiliação social? Esse conceito "desafiliação social” (SOLANO, 2010) deve ser entendido como a desconexão entre o indivíduo e a sociedade, isto é, desconexão com as instituiçóes que o protegiam e ofereciam as garantias sociais:

(...) debido a la precarización del empleo y el debilitamiento de los mecanismos de protección social erigidos por los estados de bienestar después de la segunda guerra mundial. La restructuración del capitalismo se ha acompañado a escala global por la agudización de desigualdades sociales, por el crecimiento de la pobreza y por agudos procesos de desafiliación social (...) término entendido como la desconexión gradual de las instituciones que ofrecían protección y garantías sociales, y como la pérdida de estados de equilibrio anteriores (SOLANO, 2010, p. 25-33).

Entendemos que uma das formas de um indivíduo deixar de sentir-se parte de uma sociedade é não ter um trabalho que lhe proporcione uma renda e uma vida digna, no entanto, outras dimensóes como o não acesso à saúde, à educação e às políticas sociais também devem ser consideradas para compreender a pobreza em todas suas nuances.

Desta forma, se pensarmos que existem acumulações de desvantagens durante a vida de um indivíduo, a medição da pobreza deve ser feita através da não participação das relações sociais, isto é, analisar as rupturas dos laços sociais que se revelam também em outras dimensões, como a falta de acesso aos serviços básicos (SARAVÍ, 2005).

Existem alguns limites da medição da pobreza por ingressos na região. A primeira delas é de que uma família pode estar acima da Linha de Pobreza 
e ainda assim ter carências de serviços básicos, pois vivem em bairros periféricos onde não há acesso a todos os serviços. Outra limitante que representa um problema é de que estas famílias não entram nos programas e políticas públicas desenhadas pelos governos, isto significa que estas pobrezas são invisibilizadas.

Ao ver a pobreza como um tema de falta de recursos, a consequência imediata trata-se da elaboração de políticas sociais para que a população obtenha mais recursos, a fim de satisfazer as necessidades de sobrevivência, que não resolve as raízes do problema social e nem suas dimensôes estruturantes.

Entender a pobreza como uma questão monetária e individual, ao invés de uma perspectiva social e multidimensional torna-se um problema, pois se prevê a autonomia através da renda como o meio, ocultando o seu fim que é o mercado (GUILHERME, 2018).

A partir de 2003 iniciou-se a ascensão dos governos denominados progressistas no Mercosul, a exemplo de Luiz Inácio Lula da Silva e Dilma no Brasil, Néstor Carlos Kirchner na Argentina, Fernando Lugo no Paraguai, Hugo Chávez na Venezuela e posteriormente no Uruguai José Alberto Mujica. Estes governos aderiram ao ideário de um crescimento com distribuição mais justa de renda, assim como foram realizadas políticas sociais unidimensionais (econômicas) para a redução de pobreza, através das políticas focalizadas no "combate" à pobreza extrema, que, apesar de gerar frutos importantes para a população, não promoveu um debate profundo sobre pobreza e cidadania (GUILHERME, 2018).

Assim, compartilhamos da visão do autor Christian AdelMirza, quando afirma que ainda persiste uma estrutura de desigualdade social dentro do bloco, pois em sua visão existe a necessidade de estabelecer uma estratégia para além do "combate à pobreza”, também é necessária uma estratégia de luta contra a riqueza (MIRZA, 2013a).

A política social, nesse sentido, foi tomada como uma questão de "alivio dos problemas sociais”, traduzindo-se em políticas de caráter compensatório que não tinham a pretensão de reescrever o contrato social entre o governo e o povo, o que promoveria uma cidadania de fato.

Antes de apresentar as argumentaçóes para tais considerações, entendemos que é preciso explicar como as transferências condicionadas de renda seguiram o critério da focalização, ao invés da universalização. $\mathrm{Na}$ área de políticas públicas existe o debate entre a focalização e a universalização da políticas sociais, são dois enfoques diferentes para a criação de políticas sociais. Por um lado, o critério de focalização elege o argumento financeiro como principal guia, no sentido de que o Estado deve decidir em qual 
área ou para quais pessoas devem ser realizadas as políticas sociais, isto é, a "escolha pública eficiente", em face das restrições do Estado (THEODORO, 2003).

A defesa de programas de transferência de renda são os pilares centrais dessa perspectiva, pois traz a ideia de que os que se encontram em situação de extrema pobreza, incapazes de suprir suas necessidade mínimas, porque se encontram fora do mercado de trabalho, devem ser o alvo da política social, isto é, focar em políticas de pobreza para as pessoas mais pobres e mais vulneráveis dentre os pobres. Esta concepção exclui a possibilidade da construção de um sistema amplo de proteção social, pois tem como objetivo principal apenas a focalização de grupos específicos.

Por outro lado, o enfoque da universalização das políticas sociais objetiva a universalização do acesso aos serviços públicos nas mais diversas áreas, como educação, seguridade social, saúde e mercado de trabalho. $\mathrm{Na}$ visão universalista o mercado aparece "aparece como o locus privilegiado do embate distributivo, onde, via de regra, o mais forte sempre se impóe e, em consequência, as desigualdades tenderiam a se aprofundar. Daí a necessidade da presença reguladora do Estado" (THEODORO, 2003, p. 125).

A perspectiva da focalização remete ao conceito de focopolítica, utilizada por Alvarez Leguizamón (2013) baseada em Foucault, que refere-se à ideia de autogestão da pobreza, a partir do discurso de emancipação sustentada das famílias, por meio das capacitações dos indivíduos (GUILHERME, 2018). Inclusive, esta concepção é recomendada pelo Banco Mundial, o qual trata a pobreza de forma neoliberal, meritocrática e individualizante. Segundo o BM existem duas formas de intervir na realidade, através da Focalização e das Políticas de Transferências condicionadas de renda.

Segundo Pereira (2010), o Banco Mundial se voltou para a neoliberalização da política social. Isto significa que o Banco diagnostica, prescreve e legitima programas de aliviamento paliativo e focalizado da pobreza, como instrumentos de ação dos Estados nacionais no âmbito da "questão social" (PEREIRA, 2010). Assim, podemos observar que mesmo durante os governos progressistas, houve uma reprodução dos receituários neoliberais oferecidos por organizaçóes internacionais, como o Banco Mundial, principalmente na elaboração de políticas sociais para a redução de pobreza.

Segundo Mirza, os governos de esquerda ou progressistas, desde Luiz Inácio Lula Da Silva, Dilma, Lugo e Kirchner, propuseram em seus discursos a relevância do universalismo para orientar suas reformas sociais; no entanto, mesmo na visão universalista sobreviveram critérios de focalização na abordagem sobre pobreza e indigência. Além disso, é necessário ressaltar que há uma expectativa de ordem sociológica para que isso aconteça, isto 
é, provocar modificações relativas aos setores sociais beneficiados por estas intervenções públicas (MIRZA, 2013).

Desse modo, compreendemos que as transferências de renda condicionadas não representam a estratégia mais adequada para redução da pobreza, primeiro porque ver as transferências monetárias como um sinônimo de justiça social representa um grave problema, pois isso reduz o grande e diverso debate sobre a justiça e suas dimensões redistributivas, como a representação, a participação e a política (GUDYNAS, 2012). E segundo porque torna-se um lenitivo à pobreza, devido ao seu caráter focalizado e condicional, ao ser focalizado torna-se um paliativo à um contexto maior de vicissitudes geradas pelo mercado. Ao ser condicional estabelece uma relação de tutela e de troca, entre o Estado e os que estão em situação de pobreza. Uma relação de tutela porque a maioria desses programas oferece o subsídio em troca de obrigaçôes, a exemplo de levar a criança à escola entre outros, como se uma mãe não fosse capaz de levar seu filho sem essa obrigatoriedade (MIRZA, 2013).

E uma relação de troca, porque as condicionalidades acabam transformando os direitos em obrigaçóes, receber um programa social do governo deveria ser realizado a partir do fundamento normativo baseado nos direitos sociais e acaba migrando para exigências que os beneficiários devem cumprir em troca de renda monetária. Esta questãopoderia ser resolvida "si efectivamente las politicas progresistas pusieran bincapié en el derecho de ciudadania en vez de fundarlos básicamente en el derecho a la protección" (MIRZA, 2013, p. 49).

Ademais, a proeminência das transferências monetárias na América Latina relega ao segundo plano as discussóes atinentes ao caráter estrutural da pobreza na região e ao repartimento da riqueza socialmente produzida, refletindo um caráter de controle/manutenção do status quo, frente à mitigação da fome e pobreza proporcionada por essas políticas. Não se pode perder de vista que a fome e a pobreza estão também relacionadas ao processo de acumulação selvagem existente na região, agravadas pelo prosseguimento das políticas neoliberais (ESPÍNOLA, 2018, p. 63).

Além disso, o estudo recente do Instituto de Pesquisa Econômica Aplicada (IPEA) em 2017 intitulado "Políticas públicas de transferência de renda na América Latina” mostraram que a porcentagem de investimento nestes programas não passam de $1 \%$ do Produto Interno Bruto (PIB) nos países do Mercosul (PASE, 2017).

Como dito anteriormente as transferências de renda condicionadas nascem a partir do enfoque de condicionalidades e focalização, tampouco possuem um planejamento ou debate para que futuramente possam ser 
transformadas em políticas universais e ampliadas; por isso, entendemos que a meta principal é caminhar rumo à universalização e ampliação das políticas sociais sem desconhecer as particularidades de cada país, a conjugação de políticas mais amplas que possam dar respostas às múltiplas faces da pobreza (ESPÍNOLA, 2018).

Por isso, entendendo a necessidade de uma mudança de abordagem sobre a pobreza no Mercosul, destacamos que a pobreza deve ser compreendida como um fenômeno social complexo e deve ser vista tanto como consequência quanto como estratégia dos históricos processos de exploração, subordinação e opressão, isto é, como resultado de anos de colonização, dependência e inserção internacional periférica (RAMALHO, 2017).

Entendemos que um indicador isolado não serve se não o relacionamos com outros para analisar a pobreza; por isso, é imprescindível uma abordagem multidimensional para compreender este fenômeno. Esta visão ampliada da pobreza explica de forma mais precisa as realidades dentro do bloco; por isso, apresentaremos a necessidade da aplicação de um índice de pobreza multidimensional (IPM) no Mercosul para o fortalecimento da integração social e a elaboração de políticas sociais regionais mais fidedignas às realidades.

\section{INNDICE DE POBREZA MULTIDIMENSIONAL (IPM) DO MERCOSUL}

Para fortalecer a integração social dentro do Mercosul é essencial que a visão de pobreza seja transformada, entendendo-a não apenas como um fenômeno econômico, mas como um fenômeno social complexo que possui diferentes dimensóes, diversas causas e por isso necessita de múltiplas soluçôes.

Esta transformação é uma questão sinequa non para o avanço da integração social dentro do bloco, pois a visão de pobreza está intimamente interligada à elaboração de políticas sociais e como demonstrado anteriormente a visão monetária de pobreza levou à elaboração de políticas sociais que oferecem respostas lenitivas à pobreza e distantes das realidades sociais.

Sendo assim, a primeira razão para ter um índice de pobreza em comum a partir da perspectiva multidimensional trata-se da necessidade de visibilizar as realidades de pobreza ocultas do povo do Mercosul, que estão ocultas ou que estão sendo ocultadas através dos métodos tradicionais de medição, para fins econômicos e políticos de manutenção do establishment.

Além disso, nós questionamos como podemos avançar em conjunto para dar soluçôes a este problema social comum à todos os países, se nossos olhares, nuestras miradas não se encontram? É preciso uma visão mais unificada sobre a pobreza, reservando as suas particularidades. Ressaltamos que o 
intercâmbio de experiências, o estudo em conjunto sobre a pobreza colocam-se como indispensáveis se realmente existe intenção de avançar na redução efetiva dos índices de pobreza.

Outra questão trata-se da ideia de que o índice contribuiria para a elaboração de políticas sociais em comum, auxiliando inclusive na elaboração de políticas e programas sociais mais multidimensionais, interseccionais e intersetoriais, inserindo grupos que antes não eram considerados em situação de pobreza, pois eram vistos sob o olhar unidimensional e superficial da pobreza por ingressos. O índice colaboraria também para a elaboração de políticas de redução das assimetrias internas do Mercosul.

Sabemos que as integraçóes econômica e comercial são essenciais, no entanto quando a integração social não é levada em consideração excluem-se temas relacionados à integração e proteção dos povos latino-americanos. Povos trabalhadores e trabalhadoras que constroem dia a dia a integração regional e mesmo assim não são considerados como um tema prioritário para o avanço da integração no Mercosul.

Salientamos que sem a integração dos povos latinoamericanos e a valorização de seu bem estar social, as outras integraçóes funcionariam de forma incompleta, pois faltariam mãos que trabalhem, mãos que integrem e mãos que sustentem; por isso, é crucial estudar, entender e propor soluçôes para a redução de pobreza na integração regional.

Sabemos que existem entraves e limites dentro da dimensão social do Mercosul, mas afirmamos que se realmente existe um compromisso com o avanço da integração social é preciso dar um passo atrás antes de avançar, isto é, o primeiro questionamento a ser feito é: como olhamos e medimos a pobreza? E partir destas respostas seria possível caminhar rumo à uma mudança, rumo à um método mais fidedigno às realidades de nossa população do Mercosul.

Por isso, nessa última seção temos o desafio de revelar quais são os planos de fundo, as dimensões ocultas, que de alguma forma não configuram como as dimensões principais para mensurar a pobreza, no entanto possuem relaçốes diretas com este fenômeno social. O desafio principal trata-se de permitir visualizar as pobrezas invisíveis tanto para os dados dos institutos nacionais de estatísticas como para os governos do Mercosul.

Assim sendo, consideramos que o Índice de Pobreza Multidimensional satisfaz a demanda por uma análise mais profunda e mais próxima da(s) realidade(s) sociais, assim como contribui para a elaboração de políticas regionais de redução de pobreza e por isso torna-se uma condição sinequa nonpara o avanço da integração social no Mercosul. 
O Índice de Pobreza Multidimensional (IPM) foi criado em 2010 pelo Programa das Naçóes Unidas para o Desenvolvimento (PNUD), baseado em direitos sociais universais. Utiliza uma dupla medida para avaliar pobreza: o bem estar econômico (ingresso) e os direitos (as carências sociais). Dentro das carências sociais são avaliadas as dimensôes da saúde, da educação e padrão de vida (OEA, 2013).

O método do qual estamos falando foi elaborado por Sabina Alkire e James Foster em 2010, em que através das dimensóes da vida das pessoas pode-se realizar o cálculo de Índice de Pobreza Multidimensional (IPM) (VIEIRA, 2017).

Nesse sentido, a pobreza trata-se de uma questão social que é caracterizada por diversos fatores, como a exclusão social, as condiçốes precárias de moradia, a falta de acesso à bens e serviços, à baixa escolarização entre outras. Entende-se que somente a renda não seria necessariamente um indicador suficiente para revelar a qualidade de vida da população.

O IPM tem como objetivo quantificar a pobreza de forma profunda; assim, é considerado pobre aquele que não tem suas necessidades básicas satisfeitas, conforme os parâmetros estabelecidos pelos Objetivos do Desenvolvimento do Milênio (ODM) e as pessoas identificadas como pobres necessariamente devem apresentar privaçóes que equivalham a uma dimensão completa e em algum outro indicador, assim como em caso de estar despojadas de renda e ter ao menos duas carências adicionais.

Por isso, nenhuma pessoa que apresente privação em apenas uma dimensão é identificada como multidimensionalmente pobre, o IPM é baseado em uma família de medidas desenvolvidas por Alkire e Foster em que se avaliam as dimensões de: educação, saúde, padrão de vida e particularidades. O IPM serve para avaliar a incidência e a intensidade da pobreza (OCDE/CEPAL, 2014). Dessa forma, além de recomendar que o Mercosul aplique e crie seu próprio IPM, nesta última seção realizamos um breve diagnóstico social com base no índice e em suas dimensóes, assim analisaremos os indicadores de pobreza multidimensional nos países membros oficiais do Mercosul (Argentina, Brasil, Paraguai, Uruguai e Venezuela) entre 2004 e 2019.

\section{SAÚDE}

Quando observamos a saúde entendemos que a esperança de vida deve ser uma variável analisada para compreender os níveis de saúde; isto porque os diferentes modos de vida determinam em grande medida a longevidade e qualidade da saúde das pessoas. Esta variável nos possibilita saber o nível dos riscos de doenças crônicas não transmissíveis na população, como o 
consumo regular de álcool, o sedentarismo, a obesidade, o consumo diário do cigarro e o insuficiente consumo de alimentos saudáveis como frutas e legumes.

Gráfico 1. Esperança de vida ao nascer nos países do Mercosul (anos), 2018

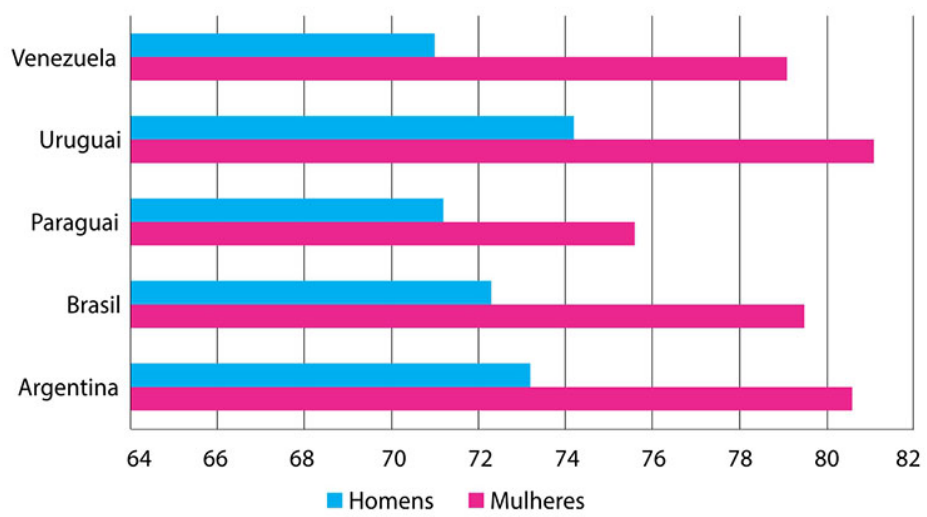

Fonte: Organização Panamericana de Saúde (OPS), 2020. Disponível em: <https://www.paho.org/data/index.php/ es/?option=com_content\&view=article\&id=515:indicadoresviz\&ltemid=348>. Acesso em: 11 nov. 2020.

Desta forma, temos uma diferença de basicamente 10 anos entre homens e mulheres, em que os dados demonstram como as mulheres nos países do Mercosul têm maior esperança de vida ao nascer do que os homens. O Uruguai (81 anos) e a Argentina (80 anos) contam com os níveis mais elevados de esperança de vida para as mulheres. Esta média é considerada alta para os parâmetros internacionais, principalmente quando comparados à outras médias na América Latina, enquanto que a Venezuela e o Brasil possuem uma média de 79 anos de vida para as mulheres e o Paraguai 75 anos.

Os países nos quais os homens possuem menores esperanças de vida ao nascer são Venezuela e Paraguai, ambos com 71 anos de idade; tanto o Brasil, o Uruguai como a Argentina atingem uma média maior que 72 anos de vida.

Além disso, ainda na área da saúde, observamos a evolução da desnutrição crônica na infância que está relacionada também ao desmame precoce, à higiene precária ao preparar alimentos, ao déficit em vitaminas e minerais e a repetição de infecçôes, como diarreias e parasitoses intestinais. 
Gráfico 2. Evolução da desnutrição crônica infantil no Mercosul entre 2004 e 2019 (menores de 5 anos, em porcentagens)

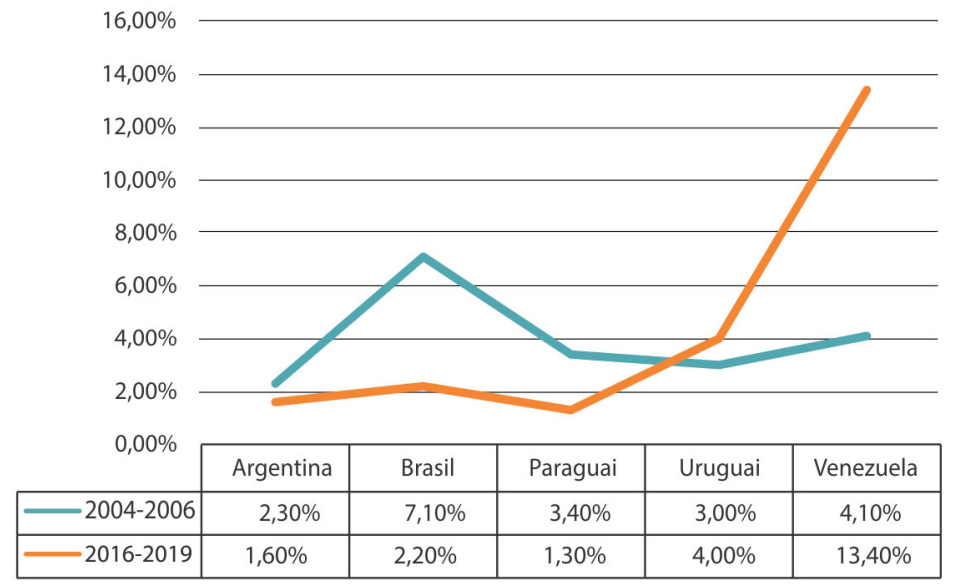

Fonte: Elaboração própria. Dados combinados da FAO, OPS, WFP e UNICEF, 2019. Panorama de la seguridad alimentaria y nutricional en América Latina y el Caribe 2019. Santiago. 135. Licencia: CC BY-NC-SA 3.0 IG0, da base de dados Cepalstat, disponível em: <https://estadisticas.cepal.org/> e <https://www.paho.org/data/index.php/es/indicadores.html >. Acesso em 05dez. 2020. Os dados do Brasil são referentes à 2006 e 2007. Dados do Uruguai referentes à 2004 e 2011.0s dados da Venezuela são de 2005 e 2009. Os dados do Paraguai são de 2005 e 2016 e os dados da Argentina são de 2005 e 2019.

Os terrenos da pobreza e da desnutrição infantil estão próximos, pois se a criança tem um bom estado nutricional isso significa que ela teve suas necessidades humanas atendidas. Em termos gerais, podemos observar que a desnutrição crônica infantil foi reduzida e se manteve esta redução no Brasil, na Argentina e no Paraguai, enquanto que no Uruguai e na Venezuela observamos o aumento da desnutrição desde 2005 , um aumento de $1 \%$ e aproximadamente $10 \%$, respectivamente.

Uma das causas que podemos atribuir à alta redução da desnutrição infantil no Brasil, de 7,1\% em 2006 para 2\% em 2019, é de que a partir de 2003 tivemos a criação do Programa "Fome Zero" do Governo Federal para erradicar a fome e a miséria no país, garantindo uma segurança alimentar e alimento de qualidade.

\section{EDUCAÇÃO}

Apresentaremos a evolução da taxa de alfabetização entre 2006 e 2018 nos países do Mercosul, assim como a conclusão da educação primária, secundária e terciária nestes países, a partir dos anos de escolaridade.

Em relação à evolução da conclusão da educação primária de pessoas com 15 anos e mais, os dados indicam que tanto no Brasil $(98,40 \%)$ como 
na Venezuela $(95,5 \%)$ e no Paraguai $(94,20 \%)$ existiu um aumento da conclusão do nível primário durante 2005 a 2018. No entanto, se analisamos o Uruguai e a Argentina, podemos ver como diminuiu em aproximadamente entre $0,5 \%$ e $1 \%$ sua taxa de educação primária, respectivamente.

Gráfico 3. Conclusão da educação primária (pessoas com 15 anos e mais com educação primária completa), 2005 e 2018

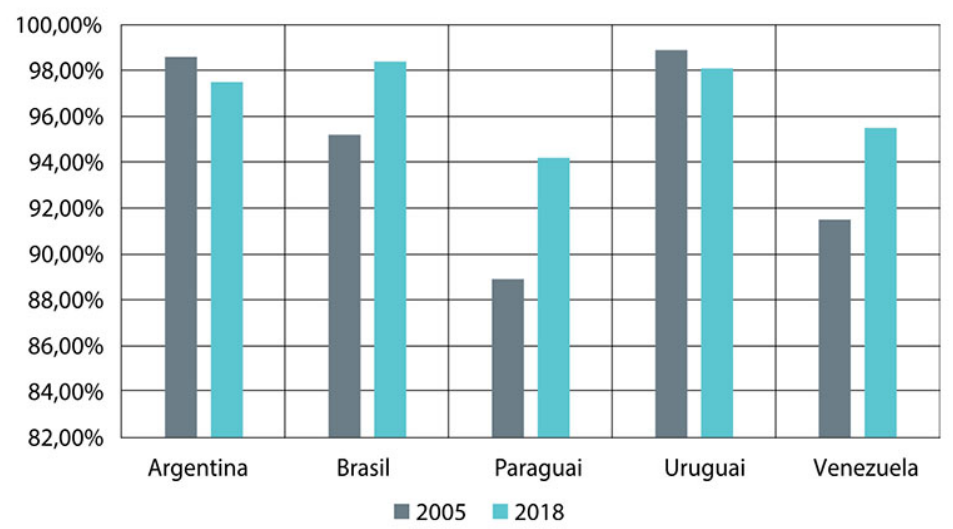

Fonte: Elaboração própria. Dados da Cepalstat, disponível em: <https://estadisticas.cepal.org/>. Acesso em 05 dez. 2020. 0s dados da Argentina são referentes aos anos de 2005 e 2019. Os dados da Venezuela são de 2005 e 2014.

A conclusão da educação secundária de pessoas com 15 anos e mais possui taxas diferentes em cada país do Mercosul. Observamos a partir do gráfico abaixo que o único país que teve uma redução da conclusão da educação secundária foi a Argentina, de 79\% em 2005 para 72,30\% em 2018. Os demais países apresentaram um aumento de suas taxas, sendo o Brasil $(73,90 \%)$ e a Venezuela $(72,60 \%)$, ambos com aumentos expressivos desde 2005, assim como o Paraguai que passou de $44 \%$ para $62,70 \%$. No caso do Uruguai houve um aumento de $28 \%$ para $41,10 \%$, sendo o índice mais baixo entre a evolução dos outros países do Mercosul.

Apesar dos altos índices de educação secundária, devemos ressaltar que na América Latina como um todo houve um movimento em que o ensino secundário ao se expandir teve um distanciamento de seu papel como preparatório para o ensino superior. As escolas preparam seus alunos para o mercado de trabalho e não necessariamente para o acesso ao ensino terciário (ABDELJALIL, 2006). Este movimento explicaria porque os níveis de ensino superior são tão baixos nos países do Mercosul.

Quando analisamos o gráfico da evolução da conclusão da educação terciária ou nível superior como também pode ser chamado, podemos ver 
que, apesar da grande evolução a partir dos anos 2000, os números continuam reduzidos para a maioria dos países, pois a maioria não alcança os $20 \%$. No Brasil podemos observar o maior crescimento desta evolução; em 2009 segundo o IBGE o país possuía apenas $7 \%$ de sua população com ensino superior, em 2014 o país tinha 14\% e em 2018 atingiu 17,40\%, configurando o maior índice dentre os países do Mercosul.

Gráfico 4. Conclusão da educação secundária (pessoas com 15 anos e mais com educação primária completa), 2005 e 2018

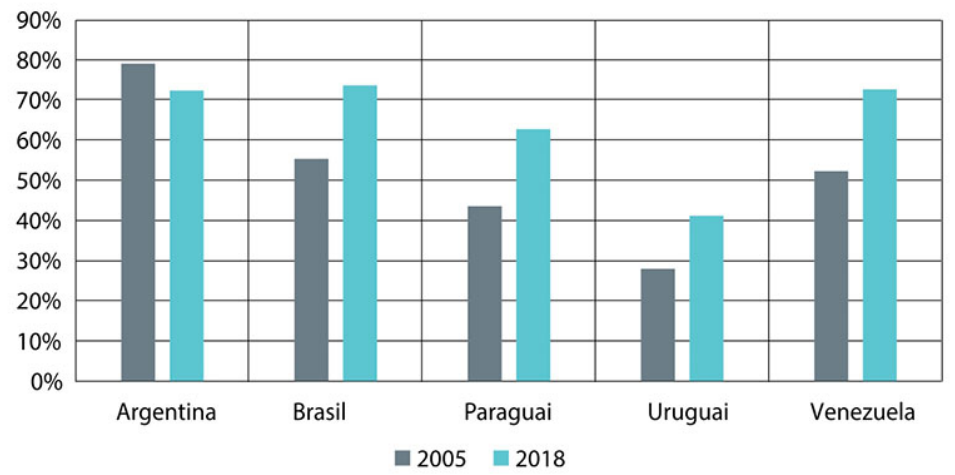

Fonte: Elaboração própria. Dados da Cepalstat, disponível em: <https://estadisticas.cepal.org/> Acesso em 05 dez. 2020.

Gráfico 5. Evolução da conclusão da educação terciária (pessoas com 20 anos e mais com educação terciária completa), 2014 e 2018

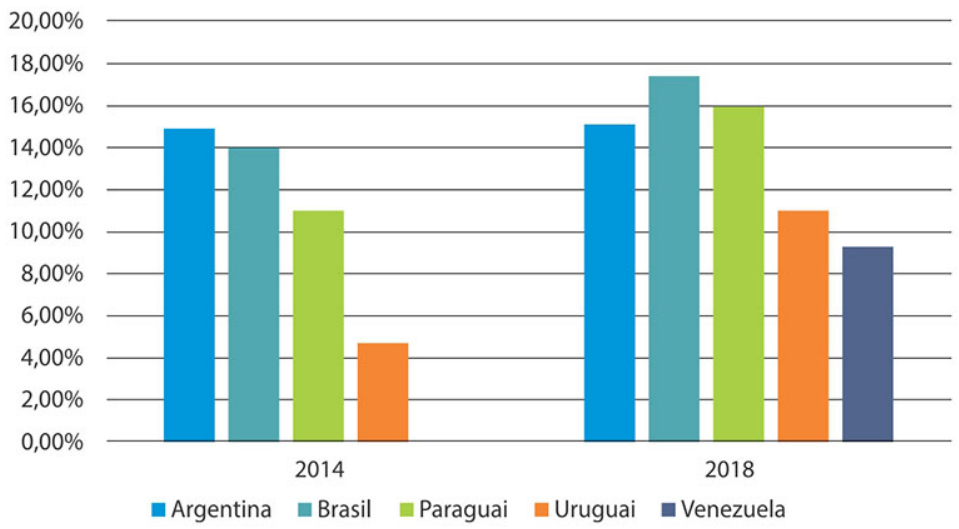

Fonte: Elaboração própria. Dados da Cepalstat, disponível em: < https://estadisticas.cepal.org/>. Acesso em 05 dez. 2020., IBGEBrasil, INE- Uruguai, INDEC-Argentina, DGEEC- Paraguai e INDEC-Argentina, acesso 12 nov 2020.0s dados da Argentina são de 2016 e 2019. Os dados do Brasil são de 2010 e 2018. Os dados do Paraguai são de 2014 e 2016. 
Ainda assim, entendemos que esta expansão no nível superior não resolveu a enorme inequidade social no acesso à educação, em que os jovens de baixa renda ainda são um número reduzido se comparado aos jovens mais ricos dentro das universidades (CEPAL, 2010).

O gráfico abaixo sobre a evolução da taxa de alfabetização nos países do Mercosul demonstra que, além dos dados que relevam os ganhos sociais durante os governos progressistas, atualmente temos dados que mostram a importância da criação de políticas reais para a alfabetização da população. De modo geral, todos os países aumentaram suas taxas de alfabetização desde 2006, em especifico a Argentina que possui a maior taxa, 99\% de alfabetizados entre 15 e 24 anos de idade, assim como o Uruguai, o Brasil e a Venezuela que possuem altos níveis de alfabetização.

Devemos ressaltar que seria interessante analisar a porcentagem de alfabetizados acima de 30 anos; no entanto, não encontramos dados comuns para todos os países, o que prova novamente a necessidade de uma base de dados sociais própria do Mercosul e de um IPM próprio.

Gráfico 6. Evolução da taxa de alfabetização de pessoas de 15 a 24 anos no Mercosul, 2006 e 2018 (em porcentagens)

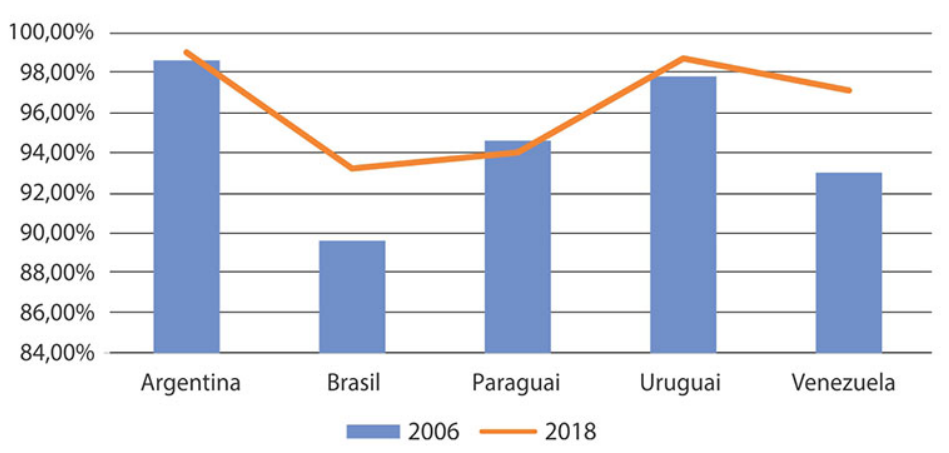

Fonte: Elaboração própria. Dados da Cepalstat, disponível em: <https://estadisticas.cepal.org/>. Acesso em 05 dez. 2020.

\section{PADRÃO DE VIDA}

O acesso à água potável é considerado um dos dados mais importantes quando estamos analisando as condições de vida da população, pois é a partir do acesso a saneamento e à água potável que diversas doenças podem ser evitadas, aumentando a qualidade de vida. Ressaltamos que o contato com esgoto e o consumo de água sem tratamento está relacionado à altas taxas de mortalidade infantil, trazendo doenças como parasitoses, diarreias, 
febre tifoide e leptospirose. Em relação ao acesso a saneamento nas zonas urbanas, os dados apontam que a Argentina (96\%), o Uruguai (96\%) e a Venezuela (94\%) estão no topo deste ranking, enquanto que Paraguai (89\%) e o Brasil (83\%) situam-se no final, com menores índices de acesso à saneamento (FERRO, 2018).

No Uruguai, segundo o estudo "América Latina y el Caribe hacialos Objetivos de Desarrollo Sostenible e nagua y saneamiento" observamos que todos os países têm altos índices de acesso a fontes melhoradas de água potável em sua área urbana, o Uruguai (100\%) e a Argentina (99\%), o Paraguai e o Brasil possuem $98 \%$ de água potável para a população urbana, enquanto que a Venezuela possui 93\%. (FERRO, 2018).

Além disso, consideramos importante analisar o não acesso a serviços básicos como à eletricidade. A partir deste gráfico, podemos observar que existe uma desigualdade grande entre o acesso dos moradores urbanos e rurais à eletricidade, pois nos três países analisados vemos como na zona rural entre $3 \%$ e $5 \%$ não tem eletricidade, além disso, a maioria pertence ao quintil 1 , isto é, pessoas com a menor renda no país.

Gráfico 7. Proporção da população sem acesso à eletricidade conforme quintil, 2000

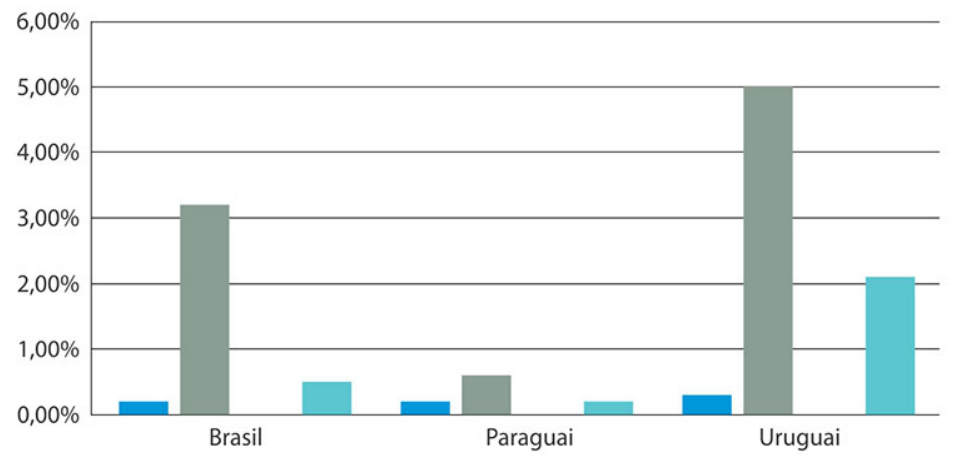

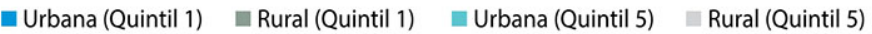

Fonte: Elaboração própria. Dados da Cepalstat, disponível em: <https://estadisticas.cepal.org/>. Acesso em: 2020.

${ }^{*} 0$ quintil 1 refere-se ao grupo de pessoas de menor renda (menores ingressos), enquanto que o quintil 5 trata-se das pessoas que recebem maiores ingressos em cada país.

Ressaltamos que não encontramos dados sobre a falta de acesso à eletricidade conforme os quintis nos outros dois países, Venezuela e Argentina, sendo que os dados da Venezuela indicam apenas as populaçóes urbanas e seu dado mais atual é de 2014, enquanto que a Argentina não está na lista de opçôes da plataforma Cepalstat. 
No entanto, encontramos dados do Observatório venezuelano de serviços públicos o qual indica que $70,8 \%$ da população possuem serviços de eletricidade, enquanto que 28,7\% não tem acesso, e os dados do estudo "Energía y pobreza enArgentina" ${ }^{3}$ mostra como 98\% dos lares argentinos possuem acesso à eletricidade, mas aproximadamente 500.000 pessoas não tem acesso e vivem em sua maioria em zonas rurais e de difícil acesso.

\section{PARTICULARIDADES}

Além das dimensões acima mencionadas, o IPM permite considerar as particularidades de cada país, isto é, dimensões que geralmente não são levadas em consideração, mas que os países consideram essenciais para mensurar a pobreza. Consideramos que este é um grande potencial do IPM, pois através das particularidades podemos vincular a desigualdade social à pobreza. Este vínculo possibilita ver como a desigualdade de gênero, racial e étnica quando vinculada à pobreza evidencia maior falta de acesso aos serviços básicos e aos direitos sociais, isto é, apresenta maiores índices de pobreza multidimensional.

Nesse sentido, quando avaliamos o lugar onde a população reside, pode-mos observar uma grande diferença de acesso aos serviços básicos entre as áreas rurais e urbanas, pois, mesmo que a pobreza seja um fenômeno comum nas duas áreas, esta manifesta-se de diversas formas, diferentes carências e desigualdades. Por exemplo, os dados da Cepalstat demonstraram que o acesso a saneamento básico e água potável na área urbana, na maioria dos países é de 90\% (CEPALSTAT, 2020).

No entanto, quando analisamos as mesmas variáveis para a área rural, a diferença é nítida: as pessoas que vivem em zonas rurais ou que pertencem aos grupos mais pobres têm geralmente menos acesso e pior qualidade de serviços, além de uma pequena cobertura de saneamento e água; no Paraguai segundo os microdados da plataforma Cepalstat em 2015 o abastecimento de água potável para sua população urbana era de acima de $80 \%$ enquanto que apenas 50\% da população rural teria acesso à águapotável.

Assim como no Uruguai, segundo dados da Cepalstat de 2019, temos que $5,8 \%$ de afrodescendentes e $4 \%$ dos povos originários da zona rural vivem sem acesso à eletricidade, enquanto que os não indígenas e não afrodescendentes do país configuram apenas 3\%. Além disso, 12,5\% desses moradores rurais uruguaios encontram-se morando em casas com materiais inadequados de construção, enquanto apenas $2,6 \%$ da população urbana vive nessas condições (CEPALSTAT, 2020). 
No Brasil, há uma porcentagem elevada de povos originários que moram na zona rural e não têm acesso à eletricidade, segundo a Cepalstat 7,9\% desta população não tem acesso. Assim, ressaltamos que eliminar esta desigualdade no acesso à água, energia e saneamento é um desafio não apenas para os países do Mercosul, mas para a América Latina como um todo (CEPALSTAT, 2020).

Gráfico 8. Média dos anos de estudos (adultos indígenas 5 a 20 anos), 2010

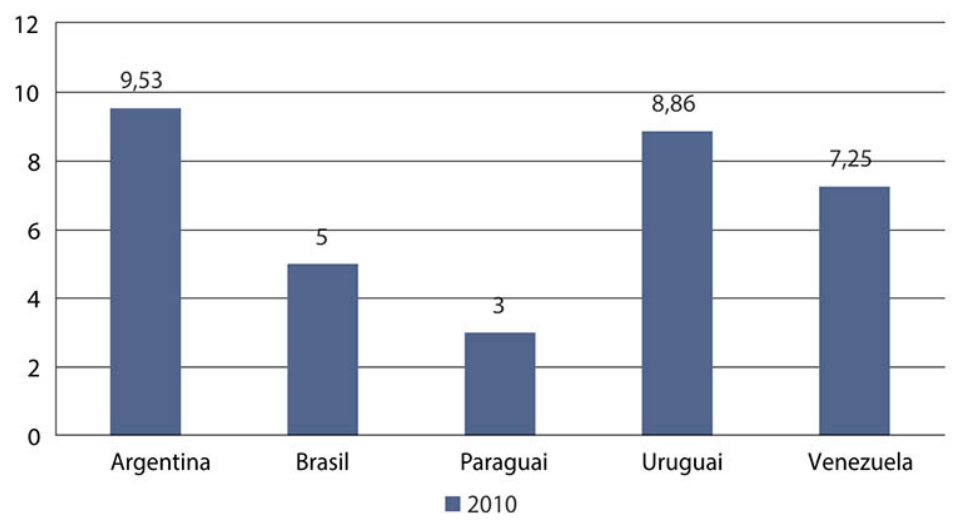

Fonte: Elaboração própria. Dados da CELADE- o fundo indígena da divisão de população da Cepal e do Sistema de Indicadores Sociodemográficos de populações e povos indígenas, disponível em: <https://redatam.org/redbin/RpWebEngine.exe/ Portal?BASE=SISPPI>. Acesso em: 12 nov. 2020.

Além disso, quando abordamos o acesso à educação, segundo dados do Centro Latino-americano e Caribenho de Demografia (CELADE) da Cepal, a média de anos de estudo dos adultos indígenas entre 5 anos e 20 anos de idade nos países do Mercosul não passam de 9 anos. Esta é uma das particularidades que demonstram como a pobreza afeta de forma incisiva os povos originários no Mercosul, pois são privados do acesso à educação. Outra questão comum aos países do Mercosul refere-se à feminização da pobreza, retratada no relatório intitulado "Que tipo de Estado? Que tipo de igualdade?” da Cepal de 2010, demonstra que as mulheres latino-americanas e caribenhas dedicam mais tempo ao trabalho não remunerado que os homens, isto é, cuidando da família, da casa e dos filhos (CEPAL, 2010a).

No Brasil, as mulheres dedicam em média 24 horas por semana ao trabalho não remunerado enquanto que os homens gastam apenas 10 horas e no Uruguai as mulheres gastam 37 horas semanais a trabalhos domésticos não remunerados enquanto que os homens 19 horas. Estes dados demonstram que, nos países do Mercosul (exceto a Venezuela por falta de dados), as 
mulheres do bloco trabalham de forma não remunerada o dobro de horas quando comparado aos homens.

Assim, conforme a autora Victoria Darling em seu estudo "Mujeres maravilla en el Mercosur Jóvenes, madres y jefas de hogaren búsqueda de visibilidad", indica que o trabalho não remunerado impossibilita que as mulheres do Mercosul possam usar seu tempo para formaçóes ou qualquer outra atividade que não seja do cuidado, como estudar, participar politicamente e trabalhar; por isso, o cuidado é um dos gargalos mais críticos da desigualdade de gênero na América Latina, este dado é de suma importância, pois impacta nos níveis de pobreza na região (DARLING, 2019).

Gráfico 9. Tempo de trabalho não remunerado, conforme sexo (Horas), 2012 a 2016

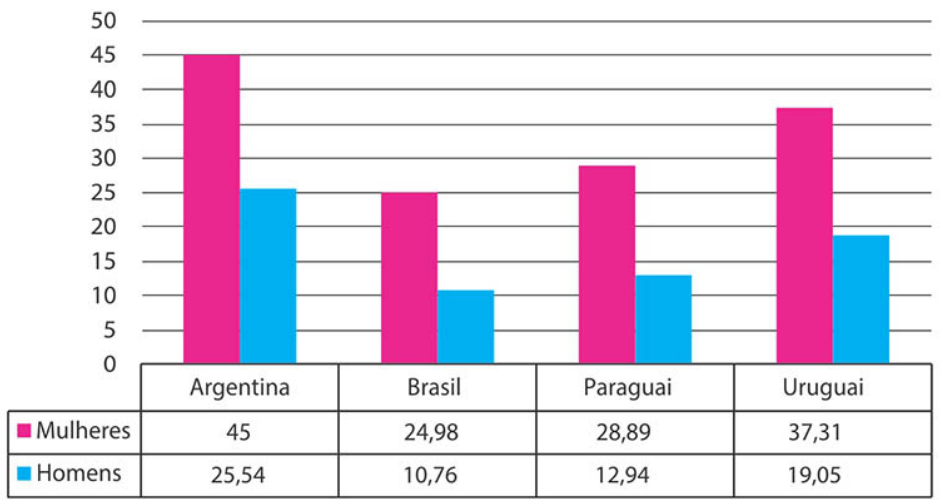

Fonte: Fonte: Elaboração própria. Dados da Cepalstat, disponivel em: <https://estadisticas.cepal.org/>. Acesso em: 05 dez.2020.

*Os dados da Argentina e do Uruguai são de 2013. Os dados do Brasi são de 2012 e do Paraguai de 2016, não foram encontrados dados desta variável para a Venezuela.

Ressaltamos que não encontramos gráficos interseccionais ou multidimensionais que abordem a pobreza em todas suas nuances na América do Sul, isto é, abordando a questão de gênero, étnica e de raça; no entanto, acreditamos que são dados cruciais para medir não somente a incidência de pobreza nas periferias, mas a intensidade dessa pobreza.

Estes dados nos demonstraram a importância da aplicação do IPM, pois permitem ver quais grupos dentro da população acabam sendo mais afetados e sofrem com a falta de serviços e acessos em seus países. Observamos a falta de dados sobre gênero, raça e etnia, o que representa um grande problema. A consequência desta falta de dados é a invisibilização de diversas pobrezas. Assim como afirma a autora Rosana Soares Campos (2017): 
A pobreza tem um componente que, se não perpetua o pobre no mundo dos pobres, dificulta a mobilidade social: a exclusão. Ser pobre é estar excluso ou incluso precariamente nas diversas esferas da vida social. (...) é um processo dinâmico, visto que os indivíduos são excluídos não apenas pela privação de trabalho ou renda, mas também devido à falta de perspectivas de futuro e a preconceitos de cor, etnia, gênero, etc (NARAYAN, 200, n.p apud CAMPOS, 2017, p.47).

Por exemplo, não há dados que analisem a pobreza das mães chefes do lar dos países do Mercosul, que mensurem qual seu nível de renda, horas de trabalho e horas de tarefas domésticas não remuneradas, sendo que esses dados seriam cruciais, pois sabemos que as mulheres ainda encontram-se em uma posição altamente desigual aos homens nos países do Mercosul.

Outros recortes devem ser feitos, como o recorte racial, a pobreza de negros e negras no Mercosul, dados que informem sobre a precariedade das situaçóes de trabalho, de renda e do bem estar em geral. Atualmente temos a base de dados da Celade/Cepal sobre povos indígenas e afrodescendentes, mas que ainda produz poucos dados comuns relativos aos países do Mercosul.

Faltam dados sobre a pobreza indígena no bloco, dados sobre as privaçóes materiais, jurídicas e simbólicas que sofrem, pois sabemos que os povos indígenas da região encontram-se em desvantagem em relação a outros setores da sociedade. Este padrão construído leva à invisibilização da situação de pobreza dos povos originários.

Assim como a pobreza rural, a maioria dos métodos que apresentamos nos países do Mercosul consideram as áreas urbanas, isto é, os censos, as entrevistas para a elaboração dos mapas de pobreza continuam sendo sobre a pobreza urbana, o que sabemos sobre as populaçóes residentes em habitaçôes rurais ainda é pequeno comparado as grandes capitais, é preciso medir as privaçôes da pobreza no meio rural.

Existe uma invisibilização, estigmatização e um negligenciamento dessas pobrezas. Isso deve mudar, esse é o papel fundamental da elaboração de novos métodos, pois permitem a descoberta e a exposição das pobrezas já existentes.

Relatamos as vantagens da aplicação do IPM, no entanto, devemos ressaltar que existem limites para a aplicação do mesmo na região. Em primeiro lugar porque a concepção multidimensional de pobreza foi originada a partir do enfoque do Desenvolvimento Humano, construído pelo Programa das Naçôes Unidas para o Desenvolvimento (PNUD), cuja referência maior é o enfoque de capacidades formulado por Amartya Sen (SILVA, 2016). 
Este continua sendo um dos limites para aplicação do IPM na região, pois o enfoque de capacidades leva ao processo de individualização da pobreza e as armadilhas da meritocracia presentes no ideário neoliberal; por isso, seria crucial a criação de um método próprio do Mercosul; no entanto, outra limitação é a falta de indicadores sociais regionais em comum.

A criação de indicadores sociais regionais torna-se essencial para que as instituições do bloco possam estabelecer políticas para reduzir as assimetrias do Mercosul. De fato, verifica-se que tais indicadores sociais dos países-membros são distintos em muitas ocasiões, o que dificulta a elaboração de medidas de caráter regional. Além disso, muitas vezes, embora os indicadores sejam os mesmos, eles tratam de assuntos diferentes, visto que existem divergências de metodologia. Daí a relevância de se instituir indicadores sociais regionais para orientar a gestação de políticas sociais de âmbito regional (SOUZA, 2010, p. 38).

Salientamos outro limite deste índice, que é sua característica homogeneizadora, sendo que no Mercosul existe uma população heterogênea; por isso, há uma necessidade da incorporação de outras dimensões para medir a pobreza no bloco.

Por exemplo, quando abordamos a dimensão sobre o padrão de vida, não pode ser uma dimensão homogeneizadora, pois os povos do Mercosul possuem múltiplos padróes de vida, diversas cosmovisôes, múltiplos Buen vivires, inclusive entendemos que o lazer deveria ser uma dimensão a ser avaliada, a possibilidade de descansar, o direito ao ócio, ao tempo livre, poder dedicar seu tempo à outros assuntos que não sejam mercantilizados. Neste trabalho não realizamos esta medição por falta de dados em comum sobre esta variável, mas consideramos imprescindível que o índice de pobreza multidimensional a ser criado pelo próprio do bloco seja capaz de captar os distintos padróes de vida para mensurar a pobreza multidimensional.

Outro limite trata-se de medir a pobreza de forma individual, a maioria dos métodos relativos à medição de pobreza consultam os indivíduos sobre sua situação, entretanto, a partir das discussões que expomos e as críticas realizadas, compreendemos que a pobreza não deve ser individualizada, afinal isso também significaria aderir ao discurso neoliberal e individualizante sobre a pobreza. Seria interessante a medição de pobreza de forma coletiva, este representaria um desafio nesta área, pois não é um forma comum de medição, mas que se torna um fator crucial se realmente se quer entender as causas reais da pobreza. 


\section{CONSIDERAÇÕES FINAIS}

Retomar a pobreza como um tema central para abordar os rumos da integração nos parece imprescindível, pois os possíveis cenários pós pandemia são alarmantes e pessimistas; por isso, será cada vez mais complexo continuar com a narrativa de uma integração meramente comercial enquanto o povo do Mercosul continua padecendo as desigualdades sociais, que infelizmente não tiveram uma reparação histórica suficiente para que a vida dessa população se transforme.

Os resultados encontrados através da aplicação do Índice de Pobreza Multidimensional (IPM) nos revelam a necessidade de transformar o nosso olhar em relação à pobreza no bloco. Atualmente os Estados membros do Mercosul mensuram seus níveis de pobreza a partir de métodos que tem como parâmetro principal a renda. Neste estudo problematizamos esta visão, pois apenas esta variável não nos indica em que condiçóes a população vive, se tem acesso à educação, saúde, moradia e qualidade de vida, somente demonstra a condição econômica de cada família; entendemos que a renda deve ser uma variável a ser considerada, no entanto não deveria ser a única.

Assim, após a análise de todas as dimensóes de pobreza, podemos concluir que a partir do IPM o conceito de pobreza se renova, a pobreza não é vista apenas como os recursos monetários, mas como um fenômeno de múltiplas dimensóes que depende principalmente do investimento do Estado. Isto reconfigura a ideia de que todo país rico tem consequentemente uma população com alto índice de bem estar social; nessa perspectiva multidimensional, um país rico é aquele que é rico em serviços e que democratiza o acesso para sua população, distribui a renda total do país a partir de investimento social de forma mais equitativa.

Nosso trabalho revelou que, quanto maior a desigualdade social, de gênero, étnica e racial, maior é a pobreza multidimensional. Além disso, as particularidades que apresentamos ao final do diagnóstico demonstram que a análise tradicional de medição de pobreza deixa a desejar quando o assunto é retratar de fato as realidades de pobreza. No método tradicional não há dados de gênero que demonstram como as mulheres no Mercosul possuem $50 \%$ a mais de horas de trabalho não remunerado semanal do que os homens ou que os povos originários não chegam aos 9 anos completos de estudo, isto significa que o acesso à educação lhes é segregado, tampouco tratam sobre a pobreza rural que indica a falta de acesso aos serviços básicos, como eletricidade e saneamento básico.

Este trabalho também evidenciou a necessidade de criar uma base de dados sociais e um IPM em conjunto para a medição de pobreza no Mercosul. Isso permitiria a possibilidade de duas questôes: primeiro fortaleceria a 
integração social dentro do bloco, aumentando a percepção sobre as situações de pobreza e possibilitaria oferecer soluções reais del Sur para el Sur, inclusive aumentando e ampliando as políticas e os programas sociais em âmbito regional, inserindo grupos que antes não eram considerados como pobres, pois eram vistos sob o olhar unidimensional e superficial da pobreza por ingressos.

Por fim, sugerimos que o Mercosul utilize algumas ideias presentes no IPM, mas que possa criar seu próprio método em comum sobre a medição de pobreza multidimensional, pois assim poderíamos ter políticas sociais orientadas para reduzir os índices de pobreza multidimensional, ao invés da elaboração de políticas públicas focalizadas e monetárias que não consideram a realidade da pobreza em todas suas nuances.

\begin{abstract}
Notas
' É importante ressaltar que Macri perdeu as eleições e o peronismo retornou na Argentina, após a vitória de Alberto Fernandez pertencente ao Partido Justicialista em 2019. "O peronista Alberto Fernández derrota Macri nas presidenciais da Argentina". El País. AgustinMarcarian. Disponível em: <https://brasil.elpais. com/brasil/2019/10/27/internacional/1572135195_737076.html>. Acesso em: 09 mar. 2021.

${ }^{2}$ A Venezuela continua suspensa do Mercosul desde 2017, sob alegação de ruptura democrática. Atualmente é governada pelo presidente Nicolás Maduro, o país continua em uma crise humanitária e política desde 2015, devido à queda dos preços do petróleo e ao intervencionismo norte-americano. "Na Venezuela, encontro contra imperialismo reúne militantes dos cinco continentes". Brasil de Fato. Michele de Melo. Disponível em: <https://www.brasildefato.com.br/2020/01/24/na-venezuela-encontro-contra-o-imperialismo-reune-militantes-dos-cinco-continentes>. Acesso em 09 mar. 2021.

${ }^{3}$ Os dados da Argentina são referentes ao estudo "Energía y pobreza en Argentina".Guillermina Jacinto, Silvina Carrizo (Conicet - Unicet y Unnoba) y Salvador Gil (ECyT y Unsam) ,Petrotecnia, 2018.Disponível em: https://bit.ly/3vBeABr. Acesso em: 17 nov. de 2020.
\end{abstract}

\title{
Referências
}

ABDELJALIL, A. As reformas do ensino secundário: as lições das transferências Norte-Sul. Educ. Rev. Belo Horizonte, n. 44, p. 257-271, dezembro de 2006. Disponível em: https://bit.ly/3u6offT. Acesso em: 10 jan. 2021.

CAMPOS, R. S. O impacto das reformas econômicas neoliberais na América Latina: desemprego e pobreza. Polis[Online], 47, 2017. Disponivel em: https://bit.ly/32Y422Z. Acesso em: 10 dez. 2020.

CEPAL (2010). Panorama Social en América Latina. La educación frente a la reproducción de la desigualdad y la exclusión: Situación y desafios en América Latina. Nações Unidas, Santiago, 2010. Disponível em: $<$ https://repositorio.cepal.org/bitstream/
handle/11362/1236/4/S2011800_es.pdf $>$. Acesso em: 15 dez. 2020.

CEPAL (Santiago de Chile, 2010a). Relatório "Que tipo de Estado? Que tipo de igualdade?". Disponivel em: <https://repositorio. cepal.org/bitstream/handle/11362/16657/1/ S1000330_pt.pdf> Acesso em: 15 dez. 2020.

CRESPO, A. \& GUROVITZ, E. A pobreza como um fenômeno multidimensional. RAE electron. São Paulo, v. 1, n. 2, p. 1-12, dezembro de 2002.

DARLING, V. Mujeres maravilla en el Mercosur en búsqueda de visibilidad. Brazilian Journal of Latin American Studies, v. 18, n. 34, pp. 95-117 
ESPINNOLA, G. M. \& ZIMMERMANN C.R. As transferências condicionadas de renda na América Latina: lenitivos para a pobreza? Revista Katálysis, Florianópolis, v. 21, n. 1, p. 55-65, jan./abr. 2018.

DGEEC - Dirección General de Estadísticas, Encuestas y Censos, Paraguai. Principales Resultados de pobreza monetária y distribución de ingresso EPHC. 2018.

FERRO, G. América Latina y el Caribe hacia los Objetivos de Desarrollo Sostenible en agua y saneamiento, CEPAL. Santiago 2017.

GUDYNAS, E. Estado compensador y nuevos extractivismos, las ambivalencias del progresismo sudamericano. Nueva Sociedad, n. 237, enero-febrero de 2012.

GUILHERME, R. C. \& REIS, C. N. dos. Plano Estratégico de Ação Social do MERCOSUL: a transferência de renda em contexto de ofensiva neoliberal. Revista Katálysis, Florianópolis, v. 21, n. 1, p. 117-124, Jan. 2018.

INDEC - Instituto Nacional de Estadística y Censos de la República Argentina. La medición de la pobreza y la indigencia en la Argentina. Buenos Aires, Noviembre, 2016.

INE - Instituto Nacional de Estatística, Uruguai. Boletín técnico. Estimación de la pobreza por el método de ingreso. 2019. Montevideo, 2020.

INE - Instituto Nacional de Estatística, Venezuela. Estadísticas de pobreza 1999-2018. Caracas, 2018.

IBGE - Instituto Brasileiro de Geografia e Estatística. Síntese de Indicadores Sociais: indicadores apontam aumento da pobreza entre 2016 e 2017. 2018.

KAGEGAMA, A. \& HOFFMAN, R. Pobreza no Brasil: uma perspectiva multidimensional. Economia e Sociedade. Campinas, v. 15, n. I (26), p. 79-112, jan./jun. 2006.s.

MERCOSUL, 2010. Proyecto de Cooperación CE-MERCOSUR en Materia Estadística II. Medición de la pobreza en los países del Mercosur : una propuesta de armonización. Grupo de Trabalho "Estatísticas para Medición de Pobreza - GT3, 2010.
MIRZA, C. A. Problemas emergentes en políticas sociales: el foco en el MERCOSUR. In: COSTA, L. C., NOGUEIRA, V. \& SILVA, V. R. (orgs). A política social na América do Sul: perspectivas e desafios no século XXI [online]. Ponta Grossa: Editora UEPG, 2013. MIRZA, C. A. \& NASCONE, M. Integración regional e inclusión social: los itinerarios del MERCOSUR. Revista do IMEA UNILA, Foz do Iguaçu, v. 1, n. 2, p. 88-99, 2013a. Disponível em: 〈https://revistas.unila.edu.br/ IMEA-UNILA/article/view/185>. Acesso em: 06 mar. 2021.

OEA. Índices de pobreza multidimensional: Compartiendo experiencias e iniciando una discusión regional. Organización de los Estados Americanos, Washington, D.C, 2013.

OCDE/CEPAL. Estudio Multi-Dimensional de Uruguay: Volumen 1. Evaluación inicial, OECD Publishing, 2014.

PASE, H. L. \& MELO, C. C. Políticas públicas de transferência de renda na América Latina. Rev. Adm. Pública, Rio de Janeiro, v. 51, n. 2, pp. 312-329, março de 2017.

PEREIRA, J. M. M. O Banco Mundial e a construção política intelectual do "combate à pobreza". Topoi, Rio de Janeiro, v. 11, n. 21, p. $260-282$, dez. 2010

RAMALHO, B., LEITE, L. H. A. \& MENDONCA, P. M. Coletivos em situação de pobreza e Educação Integral: um olhar a partir da perspectiva decolonial. In: 38a. Reunião Nacional da ANPEd, 2017, São Luís. Anais da 38a. Reunião Nacional da ANPEd, 2017.

RMADS, 2014. Proyectos y programas sociales del Mercosur en perspectiva, 2014. Disponivel em: <https://aplicacoes.mds.gov. $\mathrm{br} /$ sagirmps/ferramentas/docs/PublicacionSIMPIS_jul2014.pdf $>$ Acesso em: 10 out. 2020.

SARAVÍ, G. A. Nuevas dimensiones de la pobreza en América Latina: acumulación de desventajas y biografías de exclusión. X Congreso Internacional del CLAD sobre la Reforma del Estado y de la Administración Pública, Santiago, Chile, 18 - 21 Oct. 2005. 
SOLANO, B. C. La nueva cuestión social en el mundo y en América Latina: más allá de la pobreza. Renglones. Revista Arbitrada en Ciencias Sociales y Humanidades, n. 62, pp. 24-44, Tlaquepaque, Jalisco: ITESO, 2010.

SOUZA, A. M. E., OLIVEIRA, I. T. \& GONÇALVES, S. Integrando desiguais: assimetrias estruturais e políticas de integração no Mercosul. Texto para Discussão, n. $\mathbf{l}_{1}$, mar/2010.

SILVA, D. J. J; BRUNO, P. M. A \& SILVA, NASCIMENTO D. B. D. Pobreza multidimensional no Brasil: uma análise do período 2004-
2015. Brasil. J. Polit. Econ. São Paulo, v. 40, n. 1, p. 138-160, março de 2020.

THEODORO, M. \& DELGADO, G. Política Social: Universalização ou Focalização subsídios para o debate. IN: Políticas Sociais, IPEA, n. 7, 2003.

VIEIRA, C. A,. KUHN, D. D. \& MARIN, S. M. Método Alkire-Foster: uma aplicação para a medição da pobreza multidimensional no Rio Grande do Sul (2000-2010). Planejamento e políticas públicas, n. 48, pp. 267-299, jan./jun. 2017.

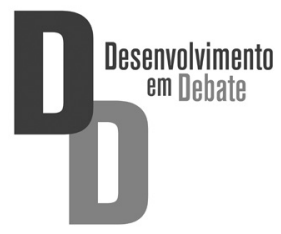

